\title{
EFFECT OF RHIZOBIUM INOCULATION WITH PHOSPHORUS AND NITROGEN FERTILIZER ON PHYSICO - CHEMICAL PROPERTIES OF THE GROUNDNUT SOIL
}

\author{
Mohammed Hasan \\ School of Environmental and Natural Resource Sciences, Faculty of Science and Technology, Universiti Kebangsaan Malaysia, Bangi, Selangor \\ 43600 UKM, Malaysia. \\ ${ }^{*}$ Corresponding author email: aldulaimi89_fst@yahoo.com. \\ This is an open access article distributed under the Creative Commons Attribution License, which permits unrestricted use, distribution, and reproduction in any \\ medium, provided the original work is properly cited.
}

\section{ARTICLE DETAILS}

\section{Article History:}

Received 12 November 2017

Accepted 12 December 2017

Available online 1 January 2018

\section{ABSTRACT}

\begin{abstract}
Low soil fertility status, nutritional imbalance and inappropriate agronomic practices are the major problems limiting the current production and yield of groundnut, therefore a study was conducted during 2015/2016 at the green house of the Universiti Kebangsaan Malaysia (UKM), Bangi, Malaysia, to evaluate the effect of Rhizobium inoculation, in combination with $\mathrm{P}$ and $\mathrm{N}$ fertilization on the growth and yield of groundnut. The experiment included plots with and without Rhizobium-inoculated treatments, two rates of P fertilizer $\left(0,82 \mathrm{~kg} \mathrm{ha}^{-1}\right)$ and two rates of $\mathrm{N}$ fertilizer $(0,27$ $\mathrm{kg} \mathrm{ha}^{-1}$ ). The treatments were laid out in a split-split plot design with two main plots (plots with and without rhizobium), two sub plots (for two Nitrogen levels) and two sub sub-plots (for two phosphorus levels), and the experiment replicated thrice. The results showed that the treatment of $\mathrm{R}^{+} \mathrm{N}_{1} \mathrm{P}_{1}$ increased significantly effect on soil pH by 5.89 units, the $\mathrm{R}^{+} \mathrm{N}_{1} \mathrm{P}_{1}$ significantly effect on Organic Matter, Soil organic $\mathrm{C}$, soil total $\mathrm{N}$, soil CEC, and available $\mathrm{P}$ by $(4.87 \%, 2.13 \%, 0.34 \%, 7.0 \mathrm{meq} / 100 \mathrm{~g}$, and $94.36 \mu \mathrm{g} / \mathrm{g}$, respectively). Based on the results of the present study, it was concluded that the soil properties can be increased with the use of $\mathrm{P}$ and $\mathrm{N}$ fertilizers along with rhizobium inoculants.
\end{abstract}

\section{KEYWORDS}

Rhizobium, chemical properties, soil fertilizers.

\section{INTRODUCTION}

The use of mineral fertilizers is paramount to enhance soil fertility $[1,2]$. However, due to the exorbitant costs of inorganic fertilizers, many smallholder farmers hardly use them to enhance their yields, and those who do so, usually apply at rates lower than the recommended application rates [3-6]. There is a need to reduce reliance on inorganic $\mathrm{N}$ for $\mathrm{N}$ depleted soils in smallholder fields. Under such scenario, adoption of grain legume crops in cereal-based cropping systems can be a plausible technological option for grain food improvement in the region.

Inoculation using Rhizobial strains is one of the strategies employed to enhance symbiotic $\mathrm{N}$ fixation by legumes, and hence improve yield in crop production systems [7]. However, poor nodulation and poor plant vigour have been observed in legumes grown in soils low in extractable $\mathrm{P}$ [8]. $\mathrm{P}$ is one of several elements which affects $\mathrm{N}$ fixation, and, along with $\mathrm{N}$, it is a principal yield-limiting nutrient in agricultural production [9]. $\mathrm{P}$ is essential for both nodulation and $\mathrm{N}$ fixation $[8,10]$. Nodules are strong sinks for $\mathrm{P}$ and range in $\mathrm{P}$ content from 0.72 to $1.2 \%$ as a consequence, $\mathrm{N}$ fixation-dependent plants will require more of this element than those supplied with combined $\mathrm{N}[11,12]$. Thus, nodulation, $\mathrm{N}$ fixation, and specific nodule activity are directly related to the P supply in the soil [10, 12]. The application of $P$ could, thus, enhance maximum exploitation of the advantages of BNF mechanism by legumes.

The current study was carried out to assess the impact of Rhizobium inoculation in combination with phosphorus and nitrogen fertilization. The combination of these inputs has demonstrated improvement in soil chemical properties.

\section{METHODOLOGY}

\subsection{Study Site Details}

The present research was conducted during 2015/2016 at the green house of UKM, Bangi, Malaysia $\left(2^{\circ} 55^{\prime} 13.1^{\prime \prime} \mathrm{N} 101^{\circ} 47^{\prime} 01.4^{\prime \prime} \mathrm{E}\right)$. The experiment was set up to study the effects of Rhizobium inoculation, in combination with $\mathrm{P}$ and $\mathrm{N}$ fertilization on the soil chemical properties.

\subsection{Experimental Design, Treatments and Measurements}

This study was conducted under greenhouse, conditions which included planting in an area of $2.5 \times 2.5 \mathrm{~m}$ for each plot. Polyethylene pots were used, each pot containing $5 \mathrm{~kg}$ of soil. Four groundnut seeds were sown in each pot, and thinned to two plants per pot, one week after seeding. The pots were frequently irrigated to maintain moisture content at field capacity, during the crop growth period [13].

The experiment was conducted using a split-split plot design with two main plots (namely with and without rhizobium), two sub plots (for two Nitrogen levels) and another two sub sub-plots (for two phosphorus levels). The experiment was replicated three times.

The details of the treatments are given below:

Treatments: -

I. Main plots: rhizobium

a. $\mathrm{R}^{+}$- rhizobium

b. $R^{-}$- without rhizobium

II. Sub-plots: Nitrogen levels

a. $\mathrm{N}_{0}$ - No Nitrogen application

b. $\mathrm{N}_{1}-100 \%$ of Nitrogen requirement (urea $27 \mathrm{~kg} / \mathrm{ha}$ i.e. $0.326 \mathrm{~g} /$ pot)

III. Sub sub-plots: Phosphorus levels

a. $\mathrm{P}_{0}$ - No Phosphorus application

b. $\mathrm{P}_{1}-100 \%$ recommended dose of phosphorus (Christmas Island Rock Phosphate (CIRP) $82.5 \mathrm{~kg} /$ ha i.e. $1.526 \mathrm{~g} / \mathrm{pot}$ ), both of fertilizers obtained from the (Agriculture Chemical Sdn. Bhd., Malaysia). Urea $27 \mathrm{~kg} / \mathrm{ha}$ i.e. $0.326 \mathrm{~g} /$ pot were applied. 
After preparation of the (80) pots, half of the groundnut seeds were inoculated with rhizobium inoculum prior to sowing and the other half was left un-inoculated as control, Phosphorus and Nitrogen fertilizers were applied at sowing stage.

\subsection{Soil Analysis}

Soil samples were analyzed for available P by the Olsen"s method and determined calorimetrically by the ascorbic acid-molybdate blue method, available N (NH4+ and NO3-) by automated caDry matterium reduction method using Auto Analyzer (FIAstarTM 5000 System), organic C Walkley and Black of colorimetric method was used and total $\mathrm{N}$ by The soil total $\mathrm{N}$ was determined by dry combustion method, soil $\mathrm{pH}$ by potentiometric method at a ratio of 1:2.5 soil:water using $\mathrm{pH}$ meter, CEC (exchangeable bases - $\mathrm{Ca} 2+, \mathrm{Mg} 2+, \mathrm{K}+$, and $\mathrm{Na}+$ ) by $1 \mathrm{M}$ ammonium acetate method at $\mathrm{pH} 7(\mathrm{Ca} 2+$ and $\mathrm{Mg} 2+$ by Atomic Absorption Spectrophotometer, Na+ and $\mathrm{K}+$ by flame photometer) [14-17]

Table 1: The initial physico- chemical properties of the experimental soil

\begin{tabular}{cc}
\hline Parameters & Values \\
\hline $\mathrm{pH}$ & 4.33 \\
CEC meq $/ 100 \mathrm{~g}$ soil & 7.42 \\
Soil moisture (\%) & 11.503 \\
Organic matter $(\%)$ & 6.257 \\
$\mathrm{Ca}^{2+}(\mu \mathrm{g} / \mathrm{g})$ & 459.03 \\
$\mathrm{Mg}^{2+}(\mu \mathrm{g} / \mathrm{g})$ & 385.142 \\
$\mathrm{~K}^{+}(\mu \mathrm{g} / \mathrm{g})$ & 840.73 \\
Phosphorus $(\mu \mathrm{g} / \mathrm{g})$ & 41.847 \\
silt $(\%)$ & 6.71 \\
clay $(\%)$ & 30.62 \\
sand $(\%)$ & 62.67 \\
Nitrate $(\mu \mathrm{g} / \mathrm{g})$ & 16.9 \\
Texture & Sandy clay
\end{tabular}

\section{RESULTS}

\subsection{Effects of Inoculation and Inorganic P on Soil Chemical Properties}

Rhizobium inoculation combined to phosphorus and nitrogen fertilizer increased soil $\mathrm{pH}$ water significantly in all treatments except in the control (table 2). $\mathrm{R}^{+} \mathrm{N}_{1} \mathrm{P}_{1}$ and $\mathrm{R}^{+} \mathrm{N}_{1} \mathrm{P}_{0}$ increased significantly 5.89 units and 5.90 units, respectively. The highest Organic Matter was recorded in the $\mathrm{R}^{+} \mathrm{N}_{1} \mathrm{P}_{1}$ and $\mathrm{R}^{+} \mathrm{N}_{1} \mathrm{P}_{0}$ treatments, $4.87 \%$ and $4.08 \%$ respectively. Soil organic $\mathrm{C}$ showed significant differences across different treatments at the initial soil sampling $(\mathrm{P}<.0 .05)$ and the highest mean $(2.13 \%)$ observed in $\mathrm{R}^{+} \mathrm{N}_{1} \mathrm{P}_{1}$. The application of Rhizobium inoculation combined to phosphorus and nitrogen fertilizer recorded the highest soil C (2.83\%) followed by treatment of nitrogen and phosphorus alone $(2.70 \%)$, while the control recorded the lowest $(2.02 \%)$.

The application of treatments significantly increased soil total $\mathrm{N}$ values in the order Rhizobium inoculation combined to phosphorus and nitrogen fertilizer $(0.34 \%)$. The treatments increased significantly $(p \leq 0.05)$ the exchangeable Ca values in the hierarchal order of treatments: $\mathrm{R}^{+} \mathrm{N}_{1} \mathrm{P}_{1}(508$ $\mu \mathrm{g} / \mathrm{g}), \mathrm{R}^{+} \mathrm{N}_{1} \mathrm{P}_{0}(480 \mu \mathrm{g} / \mathrm{g}), \mathrm{R}^{+} \mathrm{N}_{0} \mathrm{P}_{1}(484 \mu \mathrm{g} / \mathrm{g})$ over the control. The increase of soil exchangeable Mg was in the order of treatments: $\mathrm{R}^{+} \mathrm{N}_{0} \mathrm{P}_{0}$ $(171.13 \mu \mathrm{g} / \mathrm{g}), \mathrm{R}^{+} \mathrm{N}_{0} \mathrm{P}_{1}(168.95 \mu \mathrm{g} / \mathrm{g})$ followed by $\mathrm{R}^{+} \mathrm{N}_{1} \mathrm{P}_{1}(162.41 \mu \mathrm{g} / \mathrm{g}), \mathrm{R}-$ $\mathrm{N}_{1} \mathrm{P}_{1}(161.32 \mu \mathrm{g} / \mathrm{g})$. However, $\mathrm{R}^{+} \mathrm{N}_{1} \mathrm{P}_{1} \mathrm{R}-\mathrm{N}_{0} \mathrm{P}_{0}$ and $\mathrm{R}+\mathrm{N}_{1} \mathrm{P}_{0}$ treatments recorded numerically high values $(725.4,694.2$ and $663 \mu \mathrm{g} / \mathrm{g}$, respectively). The application of treatments Rhizobium inoculation + nitrogen $+\mathrm{P}$ and Rhizobium inoculation with nitrogen alone recorded the highest soil CEC values of $7.0 \mathrm{meq} / 100 \mathrm{~g}$ and $6.3 \mathrm{meq} / 100 \mathrm{~g}$, respectively. The increased in available $\mathrm{P}$ were observed in the various treatments in the order of $\mathrm{R}^{+} \mathrm{N}_{1} \mathrm{P}_{1}(94.36 \mu \mathrm{g} / \mathrm{g}), \mathrm{R}^{+} \mathrm{N}_{0} \mathrm{P}_{1}(48.07 \mu \mathrm{g} / \mathrm{g})$ and $\mathrm{R}-\mathrm{N}_{1} \mathrm{P}_{1}(46.83$

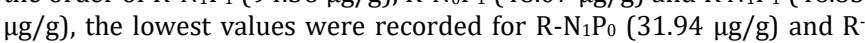
$\mathrm{N}_{0} \mathrm{P}_{0}(30.23 \mu \mathrm{g} / \mathrm{g})$ treatments.

Table 2: Effects of various treatments on Physico- chemical of soil properties.

\begin{tabular}{|c|c|c|c|c|c|c|c|c|c|c|}
\hline $\begin{array}{c}\text { Various } \\
\text { treatments }\end{array}$ & pH & $\begin{array}{l}\text { Organic } \\
\text { carbon }\end{array}$ & C\% & $\begin{array}{c}\text { Organic } \\
\text { Matter } \\
(\%)\end{array}$ & N\% & $\begin{array}{c}\text { Phosphorus } \\
(\mu \mathrm{g} / \mathrm{g})\end{array}$ & $\begin{array}{c}\text { CEC } \\
\text { meq/100g }\end{array}$ & $\begin{array}{c}\mathrm{Ca}^{2+} \\
(\mu \mathrm{g} / \mathrm{g})\end{array}$ & $\begin{array}{l}\mathrm{Mg}^{2+} \\
(\mu \mathrm{g} / \mathrm{g})\end{array}$ & $\begin{array}{c}\mathrm{K}^{+} \\
(\mu \mathrm{g} / \mathrm{g})\end{array}$ \\
\hline $\mathrm{R}^{+} \mathrm{N}_{1} \mathrm{P}_{1}$ & $5.89^{\mathrm{ab}}$ & $2.13^{\mathrm{a}}$ & $2.83^{\mathrm{a}}$ & $4.87^{a}$ & $0.34^{a}$ & $94.36^{a}$ & $6.3^{\mathrm{a}}$ & $508^{\mathrm{a}}$ & $162.41^{a}$ & $725.4^{a}$ \\
\hline $\mathrm{R}^{+} \mathrm{N}_{1} \mathrm{P}_{0}$ & $5.90^{\mathrm{a}}$ & $1.59^{\mathrm{bc}}$ & $2.11^{\mathrm{ab}}$ & $3.64^{\mathrm{b}}$ & $0.25^{\mathrm{b}}$ & $33.26^{\mathrm{b}}$ & $7.0^{\mathrm{a}}$ & $480 a^{b}$ & $160.23^{a}$ & $663^{\mathrm{ab}}$ \\
\hline $\mathrm{R}^{+} \mathrm{N}_{0} \mathrm{P}_{1}$ & $5.83^{\mathrm{ab}}$ & $1.78^{\mathrm{ab}}$ & $2.36^{\mathrm{ab}}$ & $4.08^{\mathrm{ab}}$ & $0.28^{\mathrm{ab}}$ & $48.07^{b}$ & $3.1^{\mathrm{b}}$ & $484^{a}$ & $168.95^{\mathrm{a}}$ & $592.8^{\mathrm{bc}}$ \\
\hline $\mathrm{R}^{+} \mathrm{N}_{0} \mathrm{P}_{0}$ & $5.37^{\mathrm{ab}}$ & $1.60^{\mathrm{bc}}$ & $2.13^{b}$ & $3.66^{\mathrm{b}}$ & $0.24^{\mathrm{bc}}$ & $38.7^{b}$ & $2.7^{b}$ & $452^{\mathrm{b}}$ & $171.13^{\mathrm{a}}$ & $616.2^{\mathrm{bc}}$ \\
\hline $\mathrm{R}-\mathrm{N}_{1} \mathrm{P}_{1}$ & $5.12^{\mathrm{b}}$ & $1.55^{\mathrm{bc}}$ & $2.70^{\mathrm{ab}}$ & $3.92^{\mathrm{ab}}$ & $0.22^{\mathrm{bc}}$ & $46.83^{b}$ & $2.9^{b}$ & $436^{b}$ & $161.32^{\mathrm{a}}$ & $694.2^{\mathrm{ab}}$ \\
\hline $\mathrm{R}-\mathrm{N}_{1} \mathrm{P}_{0}$ & $5.09^{\mathrm{b}}$ & $1.37^{\mathrm{bc}}$ & $2.09^{b}$ & $3.54^{\mathrm{b}}$ & $0.20^{\mathrm{bc}}$ & $31.94^{\mathrm{b}}$ & $3.05^{b}$ & $440^{\mathrm{b}}$ & $163.5^{\mathrm{a}}$ & $600.6^{\mathrm{bc}}$ \\
\hline $\mathrm{R}-\mathrm{N}_{0} \mathrm{P}_{1}$ & $5.11^{\mathrm{b}}$ & $1.49^{b c}$ & $2.31^{\mathrm{ab}}$ & $3.83^{\mathrm{b}}$ & $0.17^{b c}$ & $42.49^{b}$ & $2.1^{\mathrm{b}}$ & $472^{a}$ & $159.14^{\mathrm{a}}$ & $647.4^{\mathrm{b}}$ \\
\hline $\mathrm{R}-\mathrm{N}_{0} \mathrm{P}_{0}$ & $4.92^{\mathrm{b}}$ & $1.33^{c}$ & $2.02^{\mathrm{b}}$ & $3.15^{\mathrm{b}}$ & $0.16^{c}$ & $30.23^{\mathrm{b}}$ & $2.03^{b}$ & $404^{\mathrm{b}}$ & $153.96^{\mathrm{a}}$ & $549^{c}$ \\
\hline $\mathrm{SE}_{ \pm}$ & 0.14 & 0.09 & 0.10 & 0.17 & 0.02 & 7.34 & 0.67 & 11.64 & 1.92 & 20.40 \\
\hline LSD & 0.77 & 0.41 & 0.67 & 1.03 & 0.09 & 22.49 & 2.49 & 47.04 & 26.58 & 67.33 \\
\hline
\end{tabular}

Significant at $5 \%$ level of significance, means followed by the same letter are not significantly different by (P $\leq 0.05)$.

\section{DISCUSSION}

\subsection{Effects of inoculation and inorganic $P$ on soil chemical properties}

Soils with low $\mathrm{pH}(\mathrm{pH}<5)$ are usually of high concentration of $\mathrm{H}^{+}$and $\mathrm{Al}^{3+}$ ions in the solution, which affect negatively the availability of other nutrients (basic) for the crops. It was noted that application of P combined with Rhizobium inoculation increased soil $\mathrm{pH}$ but reduced exchangeable acidity. Marginal increase in soil $\mathrm{pH}$ was observed in some treatments involving conjoint use of Rhizobium and chemical fertilizers might be due to moderating effect of Rhizobium as it decreased the activity of exchangeable $\mathrm{Al}^{3+}$ ions in soil solution due to chelation effect of organic molecules [18].
The favorable soil conditions might have helped in greater multiplication of microbes which could convert organically bound nitrogen to inorganic form leading to build up of higher available nitrogen [19]. However, under acid soils the band placement is recommended due to $\mathrm{P}$ fixation and to increase its availability as well as use efficiency. On the other hand, Rhizobium and $\mathrm{P}$ effects require time to release soil-fixed $\mathrm{P}$ and for mineralization to take place [20]. Rhizobium application might have resulted in a significant increase in its content which might be ascribed to the additional of magnesium in soil as it contains of magnesium. These observations are in accordance with those of the earlier reports [21,22]. 


\section{CONCLUSION}

It may be concluded from the above study that rhizobium inoculated groundnut responses to all the treatments which obtained rhizobium inoculated, and the highest yield was obtained when $\mathrm{P}$ and $\mathrm{N}$ fertilizer were added in combination with the inoculant. Soil properties can be increased with the use of $\mathrm{P}$ and $\mathrm{N}$ fertilizers along with rhizobium inoculants.

\section{REFERENCES}

[1] Warren, G.P., Micheni, A.N. 2007. Effects of manure application on crop yield and soil chemical properties in a long-term field trial in semiarid Kenya. In Bationo, A., Waswa, B., Kihara J., Kimetu, J. (eds.). Advances in Integrated Soil Fertility Management in sub-Sahara Africa: Challenges and opportunities. Pp 471-485. Limburg: Springer.

[2] Sangina, N., Woomer, P.L. (eds.) 2009. Integrated Soil Fertility Management in Africa: Principles, Practices and Developmental Process, 123-140. Nairobi: CIAT.

[3] Kihanda, F.M., Warren, G.P., Micheni, A.N. 2007. Effects of manure application on crop yield and soil chemical properties in a long-term field trial in semi-arid Kenya. In Bationo, A., Waswa, B., Kihara J., Kimetu, J. (eds.). Advances in Integrated Soil Fertility Management in sub-Sahara Africa: Challenges and opportunities, 471-485. Limburg: Springer.

[4] Okalebo, J.R., Othieno, C.O., Woomer, P.L., Karanja, N.K., Semoka, J.R.M., Bekunda, M.A., Mukhwana, E.J. 2006. Available technologies to replenish soil fertility in East Africa. Nutrient Cycling in Agroecosysytems, 76, 153170.

[5] Saidou, A.K., Abaidoo, R.C., Singh, B.B, Iwuafor, E.N.O., Sanginga, N. 2007. Variability of cowpea breeding lines to low phosphorus tolerance and response to external application of phosphorus. In Bationo, A., Waswa, B., Kihara J., Kimetu, J. (eds.). Advances in Integrated Soil Fertility Management in Sub-Sahara Africa: Challenges and opportunities, 413421. Dordrecht: Springer.

[6] Shisanya, C.A., Gitonga, N.M. 2007. Evaluation of nitrogen fixation using $15 \mathrm{~N}$ dilution methods and economy of a maize-tepary bean intercrop farming system in semi-arid SE-Kenya. In Bationo, A., Waswa, B., Kihara J., Kimetu, J. (eds.). Advances in Integrated Soil Fertility Management in Sub-Sahara Africa: Challenges and opportunities, 389400. Dordrecht: Springer.

[7] Amba, A.A., Agbo, E.B., Garba, A. 2013. Effect of nitrogen and phosphorus fertilizers on nodulation of selected grain legumes at Bauchi, Northern Guinae Savanna of Nigeria. Journal of Biosciences, 3 (10), 1-7. [8] Kamanga, B.C.G., Whitbread, A., Wall, P., Waddington, S.R., Almekinders, C., Giller, K.E. 2010. Farmers Evaluation of Fertilizer Application to Annual Legumes. In Chisepo, Central Malawi. African Journal of Agricultural Research, 5, 668-680.

[9] Zahran, H.H. 1999. Rhizobium-legume symbiosis and nitrogen fixation under severe conditions and in an arid climate. Microbial and Molecular Biology Reviews, 63 (4), 968-989.
[10] Sul, W.J., Asuming-Brempong, S., Wang, Q., Tourlousse, D.M., Penton, C.R., Deng, Y., Cole, J.R. 2013. Tropical agricultural land management influences on soil microbial communities through its effect on soil organic carbon. Soil Biology and Biochemistry, 65, 33-38.

[11] Hart, A.L. 1989a. Nodule phosphorus and nodule activity in white clover. New Zealand Journal of Agricultural Research, 32, 145-149.

[12] Hart, A.L. 1989b. Distribution of phosphorus in modulated white clover plants. Journal Plant Nutrition, 12, 159-171.

[13] Singh, G.P., Singh, P.L., Panwar, A.S. 2011. Response of groundnut (Arachis hypogeae L.) to biofertilizers, organic and inorganic sources of nutrient in North-East India. Legumes Research, 34, 196-201.

[14] Olsen, S.R., Watanabe, F.S. 1963. Diffusion of phosphorus as related to soil texture and plant uptake. Soil Science Society of America Journal, 27 (6), 648-653.

[15] Okalebo, J.R., Gathua, K.W., Woomer, P.L. 2002. Laboratory methods of soil and plant analysis: a working manual (2nd ed.). Nairobi: TSBFCIAT and Sacred Africa.

[16] Ukovich, M., Herridge, D., Peoples, M., Cadisch, G., Boddey, R., Giller, K., Alves, B., Chalk, P. 2008. Measuring plant-associated nitrogen fixation in agricultural systems. ACIAR Monograph No. 136-258.

[17] Chapman, H.D. 1965. Cation-exchange capacity. In: C. A. Black (ed.) Methods of soil analysis - Chemical and microbiological properties. Agronomy, 9, 891-901.

[18] Kisinyo, P.O., Gudu, S.O., Othieno, C.O., Okalebo, J.R., Opala, P.A., Maghanga, J.K., Agalo, J.J., Ng'etich, W.K., Kisinyo, J.A., Osiyo, R.J., Nekesa, A.O., Makatiani, E.T., Odee, D.W., Ogola, B.O. 2012. Effects of lime, phosphorus and rhizobia on Sesbania sesban performance in a Western Kenyan acid soil. African Journal of Agricultural Research, 7 (18), 2800 2809.

[19] Bhardwaj, S.K., Kaushal, R., Sharma, Y. 2010. Effect of conjoint use of enriched compost and chemical fertilizers on the yield and nutrient uptake in pea (Pisum sativum L.) under mid-hill conditions. Himachal Journal of Agricultural Research, 36 (1), 101-104.

[20] Maerere, A.P., Kimbi, G.G., Nonga, D.L.M. 2001. Comparative effectiveness of animal manures on soil chemical properties, yield and root growth of amaranthus (Amaranthus cruentus L.). African Journal of Science and Technology, 1 (4), 14-21.

[21] Ansari, A.A., Sukhraj. 2010. Effect of vermin-wash and vermincompost on soil parameters and productivity of okra (Abelmoschus esculentus) in Guyana. Pakistan Journal of Agricultural Research, 23 (34), $137-142$

[22] Renato, Y., Ferreira, M.E., da Cruz, M.C.P., Barbosa, J.C. 2003. Organic matter fractions and soil fertility under the influence of liming, vermicompost and cattle manure. Scientia Agricola, 60 (3), 549-557. 